\title{
Emancipations and the Economy of the Cape Colony
}

\author{
ROBERT ROSS
}

Immediately after the Belgian Congo's independence, the commander of the army, General Janssens, called together the Congolese officers and harangued them in front of a blackboard on which was written After independence $=$ before independence' ${ }^{1}$ This was equally the attitude of slaveowners throughout the colonial world to the ending of slavery. Slavery was not abolished anywhere as a result of the slaveowners' collective munificence but was always imposed on them by some outside force. The slaveowners' reaction was to attempt to minimize the consequences of emancipation and to re-establish, as far as possible, the status quo ante. In the long term, of course, they did not succeed, although their failure was not as comprehensive as in the Congo, where the army mutinied the very day of Janssens's lecture. The economic arrangements characteristic of slave societies have disappeared, though what has taken their place may be more or less similar to slavery. Indeed social relationships in the rural Cape have probably been more like slavery for longer than in most other countries where the slaves were freed. In the medium term, however, the various slave societies experienced variations on a relatively small number of possibilities. Some

of the outcomes were more favourable to the slaveowners than others. In general this also meant that they were less favourable to the slaves.

There are, of course, a variety of criteria by which the outcome of emancipation can be measured, and the results of judgements based on differing criteria are unlikely to be the same. Slavery oppressed its victims economically, more purely socially, politically and psychologically, at the very least. To the extent that these matters can be disentangled, its legacy can be analysed along any of these lines. However, it should not be forgotten that in the great majority of at least those slave societies which derived from European colonial expansion, slavery was at bottom an institution for the organization of production. This paper will address the question of the effects of emancipation upon the levels of production, agricultural and other, within the Cape Colony. 
In so doing, of course, it is important to realize that there were two emancipations at the Cape, not one. As in the rest of the British Empire (outside India), ${ }^{2}$ slaves were freed in 1834 , although for four years thereafter they were held as apprentices' under restriction, which differed hardly if at all from those which had been imposed on them under slavery. However, before the promulgation of Ordinance 50 in 1828, the colony's Khoisan suffered under civil disabilities as a result of which their de facto position only differed from slavery in that they could not be sold, or in any other ways transferred from one master (or mistress) to another. Thus emancipation, even as legal concept, was a process which covered at least a decade, not a single event

From its foundation in the mid-seventeenth century, the Cape Colony had been largely dependent on slave labour. The households of Cape Town, both of the officials and of the burghers, soon acquired significant numbers of slave domestic servants. The Company needed slaves to work its gardens and to load and unload its ships. Slave artisans were employed in the various workshops that sprung up in the town. From around 1690 the shale hills of the Zwartland, north of Cape Town, were parcelled out into wheat farms and the valley lands of Stellenbosch, Drakenstein and the Waggonmakers Valley (Wellington) were opened up as vineyards. ${ }^{3}$ These were heavily dependent on slave labour. Indeed, throughout the eighteenth century over 90 per cent of arable producers owned at least one slave, a remarkably high proportion. But the slaves were not the only labourers on the farms. As the eighteenth century progressed, the indigenous Khoisan of the Cape were increasingly robbed of any independent access to grazing lands and hunting territories. As a result they were forced to become labourers on the farms. By 1806, even in the largely arable Stellenbosch and Drakenstein districts, over 30 per cent of the labour force was Khoikhoi. ${ }^{5}$ In the pastoral districts to the east of the mountain chains some 50 miles from Cape Town this proportion would have been much higher. The expansion of trekboers into the South African interior, a process which marked the whole of the eighteenth century and much longer, would have been inconceivable without the subjugation and use of Khoisan labourers.

In the early part of the nineteenth century the slave-based agrarian economy of the Western Cape was fully intact. Indeed, the production of wine nearly doubled between 1808 and 1824 as wine farmers profited from the opening of the British market to Cape wines. Thereafter a period of decline set in as the tariff advantages which Cape wine had enjoyed in Great Britain, as against French vintages, were very sharply reduced. ${ }^{6}$ There was also a steady rise in grain production. In particular the cultivation of barley, oats and rye increased very sharply, three to 
fourfold between 1806 and 1834 , in response to the improved market provided by the British army and its cavalry. The increase in wheat production, on the other hand, was much slower, so much so that a couple of bad years, as in the early $1820 \mathrm{~s}$, could make a trend based on five-year averages appear negative. Nevertheless, in general there was a steady rise in agricultural production throughout the first quarter of the nineteenth century.

This rise in production, sharper than at any stage during the eighteenth century, occurred despite the abolition of the slave trade in 1807. By the early nineteenth century the Cape's slave population was just about reproducing itself, but the transition from a heavily immigrant population, with a high over-representation of adult men, clearly entailed some decrease in the quantity of labour available. In 180635 per cent of the slaves were children (defined as males under the age of 16 and females under the age of 14); by 1824 , under the same definition, this proportion had risen to 42 per cent. ${ }^{7}$ There were two other new sources of bonded labour for the agricultural districts. A certain number of slaves seem to have been sold from Cape Town to the country districts as owners profited from the increasedprices in the latter sector. ${ }^{8}$ Some recaptured Africans (or 'prize negroes') also found their way to the countryside, although the majority of these remained in Cape Town. ${ }^{9}$ Nevertheless, these two groups together were almost certainly too few to allow the labour force on the wine and grain farms to grow at a rate commensurate with the increase of production. The result would thus seem to have been an increase in the pressure on labourers to work harder.

In the other main sectors of the Cape's economy, Cape Town and the frontier, the early nineteenth century brought notably different developments. In the former, as Andrew Bank's recent research has shown, the institution of slavery was eroding away ${ }^{10}$ On the frontier, in contrast, bonded labour was increasing sharply, in step with the developing complexity of colonial economic life there. The number of legal slaves in the Eastern Districts was growing slowly, though faster than that of the colony as a whole, during the early nineteenth century. A number of Africans from north of the Orange, conservatively estimated at 500 , were held in contravention of the law and some may have been fraudulently registered as slaves. More importantly, many of the Khoisan of the Southern and Eastern Cape were reduced to de facto serfs."

The enserfment of the Khoisan was a process which began with the extremely violent conquest of the Cape interior during the eighteenth century. Colonial settlement entailed the wresting of the land from the Khoisan, although in general those who had cattle and sheep were still able to run them on farms claimed by Europeans. Nevertheless, labour 
discipline was maintained by the use of force. The stories of brutality in early colonial Graaff-Reinet are widely confirmed in the archival record. The result was not just the Khoisan rebellion of 1799 but also considerable psycho-social dislocation among the Khoisan which manifested itself in a whole series of disturbing dreams and visions. ${ }^{12}$

With British conquest of the Cape, firmly established in 1806 , the colonial government attempted to play Leviathan, to impose regulation on a world of unrestrained power. The codes of labour legislation issued by the Earl of Caledon in 1809 and by his successor as Governor, Sir John Cradock, in 1812, were ostensibly designed to protect the Khoikhoi from genocide. If this was ever a threat, they succeeded, in combination with the beginnings of a civil and military administration in the East. After 1809 the reports of brutality on the farms of the Eastern Cape die sharply. The price that was paid for this, however, was a code of labour legislation which tied the Khoisan to their white employers by one-sided contracts, by a system of apprenticeship, forcing children (and by extension their parents) to remain on a farm until they were 25 , and by prohibitions on mobility and landownership. 14 In addition, payment was often in stock, so that the refusal to allow men and women to leave a farm with their stock and the harassment of those who were on the road seeking work meant that a large proportion of the Khoisan were tied to particular farms. On these they were treated as slaves, but did not have the protection which slaves enjoyed as the living repositories of the masters' capital. These practices were the target of John Philip's Researches in South Africa, the first great work of campaigning journalism to come out the country. ${ }^{15}$ Only for those who managed to gain access to one of the mission stations was there any chance of escape.

How, then, did the agricultural economy of the Cape Colony fare after the emancipations? Essentially, the subsequent two decades saw a long boom, if the inevitable but relatively minor fluctuations in the conjuncture are discounted. This can be shown most clearly from the production figures presented in Tables 1 and 2 . Table 1 gives production figures, derived from the Cape Blue Books, ${ }^{16}$ for the main slave-grown crops, grain (wheat, barley, oats and rye) and wine, with its derivative brandy. It shows that the production of grain was scarcely affected even in the medium term by the emancipation of slaves, or rather, if anything, emancipation led to an increase in production. It is perhaps possible on the basis of the figures alone to conclude that the effective emancipation of slaves occurred in 1838 , although the fact that there was a drought in that year makes the prediction easier. ${ }^{17}$ In that year production of both wheat and oats and rye (which for reasons of recording have to be taken together) were lower than in any year in either the previous or the 
subsequent decade, while the production of barley was only marginally higher than that of the previous year, which was the minimum for the period $1828-46 .^{18}$ In the subsequent one, or perhaps two, years production was also low. However, if the period 1829-34 (excluding 1832) is compared with that between 1842 and 1846 , then the speed of the recovery from the effects of emancipation becomes clear. The production of both wheat and oats and rye is 35 per cent higher in the latter period than in the former, while that of barley is lower, but only by 7 per cent.

TABLE 1

PRODUCTION OF AGRICULTURAL COMMODITIES

\begin{tabular}{|c|c|c|c|c|c|}
\hline Year & $\begin{array}{l}\text { Wheat } \\
\text { bushels }\end{array}$ & $\begin{array}{l}\text { Barley } \\
\text { bushels }\end{array}$ & $\begin{array}{c}\text { Oats/Rye } \\
\text { bushels }\end{array}$ & $\begin{array}{c}\text { Wine } \\
\text { leggers* }\end{array}$ & $\begin{array}{l}\text { Brandy } \\
\text { leggers }\end{array}$ \\
\hline 1828 & 322,635 & 351,188 & 329,928 & 20,405 & 1,413 \\
\hline 1829 & 520,768 & 300,625 & 321,570 & 15,539 & 1,060 \\
\hline 1830 & 410,472 & 224,676 & 283,785 & 14,977 & 1,845 \\
\hline 1831 & 443,693 & 271,147 & 282,182 & 18,467 & 1,382 \\
\hline 1832 & 306,063 & 282,380 & 275,106 & 16,973 & 1,394 \\
\hline 1833 & 528,147 & 286,197 & 237,012 & 14,501 & 1,207 \\
\hline 1834 & 540,528 & 257,602 & 276,553 & 12,005 & 1,075 \\
\hline 1835 & $\mathrm{NA}$ & & & & \\
\hline 1836 & $\mathrm{NA}$ & 218,490 & 241,185 & 16,693 & 1,282 \\
\hline 1837 & 494,280 & 220,534 & 211,535 & 18,103 & 1,373 \\
\hline 1838 & 463,691 & 180,847 & 187,860 & 21,915 & 5,846 \\
\hline 1839 & 395,329 & 203,323 & 185,759 & 22,899 & 5,861 \\
\hline 1840 & 433,454 & 244,600 & 197,663 & 20,229 & 6,190 \\
\hline 1841 & 471,804 & 295,718 & 215,006 & 25,312 & 6,161 \\
\hline 1842 & 592,054 & 271,983 & 286,075 & 18,299 & 1,653 \\
\hline 1843 & 705,647 & 242,662 & 392,672 & 13,426 & 1,386 \\
\hline 1844 & 771,760 & 293,569 & 419,587 & 16,412 & 2,075 \\
\hline 1845 & 650,849 & 262,912 & 436,526 & 17,156 & 1,996 \\
\hline 1846 & 579,421 & 180,856 & 350,159 & 18,640 & 2,069 \\
\hline 1847 & JA & 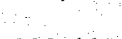 & & & \\
\hline 1848 & 516,219 & 233,667 & 248,615 & 10,308 & 1,671 \\
\hline 1849 & 585,325 & 265,663 & 249,307 & 19,943 & 2,151 \\
\hline 1850 & $\mathrm{NA}$ & & & & \\
\hline 1851 & $\mathrm{NA}$ & & & $\because$ & \\
\hline 1852 & 721,775 & 244,432 & 451,981 & 16,261 & 2,418 \\
\hline 1853 & 864,272 & 302,753 & 846,520 & 23,705 & 3,393 \\
\hline 1854 & $1,012,488$ & 424,134 & 925,235 & 23,088 & 3,891 \\
\hline 1855 & 994,273 & 400,237 & $2,308,777$ & 23,640 & 3,797 \\
\hline
\end{tabular}

Source, G.McC. Theal (ed), Records of the Cape Colony, 36 volumes (London: Cape Colony Blue books, 1895-1906).

A A legger consists of about 152 gallons, or 680 litres. 
TABLE 2

STOCK NUMBERS IN THE CAPE COLONY

\begin{tabular}{|c|c|c|c|c|}
\hline Year & oxen & Other cattle & Wooled Sheep & African sheep \\
\hline 1828 & & 357,531 & & $2,181,952$ \\
\hline 1829 & & 322,021 & & $1,839,402$ \\
\hline 1830 & & 311,938 & & $1,905,728$ \\
\hline 1831 & & 315,355 & & $1,087,614$ \\
\hline 1832 & & 334,907 & & $1,923,132$ \\
\hline 1833 & & 343,644 & & $1,960,886$ \\
\hline 1834 & & 312,569 & & $1,919,778$ \\
\hline 1835 & $\mathrm{NA}$ & & & \\
\hline 1836 & $\mathrm{NA}$ & & & \\
\hline 1837 & & 279,818 & & $1,923,082$ \\
\hline 1838 & & 266,255 & & $2,030,145$ \\
\hline 1839 & & 306,809 & & $2,339,191$ \\
\hline 1840 & & 334,201 & & $2,456,176$ \\
\hline 1841 & & 377,803 & & $3,008,613$ \\
\hline 1842 & & 451,852 & & $3,706,791$ \\
\hline 1843 & & 452,886 & & $3,949,354$ \\
\hline 1844 & & 471,635 & & $4,513,534$ \\
\hline 1845 & & 466,558 & & $4,557,227$ \\
\hline 1846 & 122,720 & 210,082 & $1,502,611$ & $1,740,835$ \\
\hline 1847 & NA & & & ( \\
\hline 1848 & 169,877 & 249,189 & $2,093,074$ & $2,042,767$ \\
\hline 1849 & 198,899 & 390,485 & $2,283,232$ & $2,114,919$ \\
\hline 1850 & NA & & & \\
\hline 1851 & $\mathrm{NA}$ & & & \\
\hline 1852 & 203,058 & 291,600 & $2,651,136$ & $1,679,941$ \\
\hline 1853 & 198,542 & 273,112 & $3,476,209$ & $1,528,386$ \\
\hline 1854 & $\mathrm{NA}$ & & & \\
\hline 1855 & 157,886 & 292,142 & $4,827,926$ & $1,625,857$ \\
\hline
\end{tabular}

Source. as Table 1.

* Until 1846 no consistent distinction was made between oxen and other forms of cattle, nor between wooled (or merino) and the indigenous, hairy Cape sheep.

For grape products the situation is complicated, but in an interesting way. The figures demonstrate that the period around and immediately subsequent to emancipation saw the high point of both wine and, in particular, brandy production. More wine was pressed between 1838 and 1841 than in any other four year period for which there is information between 1806 and 1855, while more than twice as much brandy was distilled in each of those four years than in any other year before the 1850s. In part this may represent a recovery from the depression which had followed the bursting of the wine boom in the $1820 \mathrm{~s} .{ }^{19}$ More importantly, this phenomenon was, paradoxically enough, a response to tem- 
porary labour shortage. In general, there is a trade-off between the quantity of the wine produced in any vineyard and its quality. If there is a reduced input of labour at certain crucial stages of the agricultural year, notably when the vines have to be pruned, then the amount of juice which can be eventually pressed from the grapes will be considerably higher, but, since its sugar content will be lower, the wine that can be made from it will be much worse. What seems to have happened is that a decrease in the care exercised over the husbandry of the vineyards increased the total supply of wine, but that much of it was so bad that farmers had no option but to convert it into brandy, normally and aptly known as "Cape Smoke'. ${ }^{20}$

The other main sector of the colony's agriculture (sensu lato) was stock farming. As a general rule, the sheep and cattle which were held on the enormous ranches of the Cape's interior were herded less by slaves, and more by Khoisan, whose condition in the first quarter of the nineteenth century was if anything worse than that of the slaves. It follows that the lifting of all civil disabilities on the Khoisan, and other free 'coloureds', by the measure known as Ordinance 50 of 1828 , was probably more important than the emancipation of slaves in many of the Eastern districts of the colony. ${ }^{21}$ As is shown in Table 2 , there was no fall-off in potential production as a result of Ordinance 50 , or indeed of the emancipation of slaves a decade later. The figures are less self-evident than in the case of agriculture because frontier wars, notably those of 1835,1846 and $1850-53$, could reduce the colony's flocks and herds fairly drastically, and it took several years for them to recover. All the same, it is clear, on the one hand, that the colony's herds and flocks increased steadily, if unevenly, and, on the other, that the export of wool rose dramatically in the years after emancipation, from around half a million pounds in 1838 to about 12 million in $1855 .^{22}$

How was this degree of continuity achieved? Since there were no major imports of labour into the colony in the immediate aftermath of the emancipations, ${ }^{23}$ the most plausible explanation would seem to be that farmers were able in some way to maintain their hold on their labourers, in other words that they were able to transform legal and quasi-legal bondage into other forms of dependency. Nevertheless, it would be a mistake to assume a priori that matters of labour organization were sufficient in themselves. Therefore, it is necessary first to investigate those other economic factors which may have had a considerable, or even a decisive, influence on the outcome.

The first of these, of course, is the market. In analysing the trends in the market for Cape produce, it is necessary to make a sharp distinction between the various sectors of agricultural and pastoral production. of 
these, wine farmers were by far the most dependent on exports before the 1840 s. Between 1825 and 1829 as much as 50 per cent of wine produced in the colony was exported, most of it to Great Britain, although there were growing, if temporary, markets in the southern hemisphere, notably in Australia. These were seemingly the most heavily hit by emancipation. At the high point of wine exports, in the 1820 s, on average more than five and a half thousand leggers of wine were sent annually to Britain. This had declined to just over three and a half thousand by the early $1830 \mathrm{~s}$, and by $1840-44$ was no more than 2,365 leggers a year. ${ }^{24}$ It may be that part of the decline was a result of a hypothesized decrease in the quality of Cape wine as labour became short, but it is much more likely that rumours of British tariff changes were responsible. In 1831 the British government passed a law by which the differentials on duties between Cape wine and that from continental Europe were greatly decreased, and in 1840 rumours reached Cape Town that a tariff agreement between Britain and France would further weaken the competitive position of Cape winein its major export market. The result was that Cape wine merchants were unwilling to risk shipping wine to Britain where it might prove unsaleable. ${ }^{25}$ Even though these rumours proved untrue, Cape wine was unable to recapture the market share that it had once held.

The result for Cape wine farmers was a period of decline. In the early years, in 1843 and 1844 , wine production was lower than it had been for two decades. However, this fall did not occur until well after emancipation. Moreover, perhaps as early as 1846 , and certainly by the 1850 s, there were clear signs of recovery, even though the proportion of wine exported continued to fall sharply. The internal market of the Cape was evidently able to absorb significantly more wine, and the vineyards of Stellenbosch and surrounding areas could produce it.

Grain farming, on the other hand, which in terms of value produced was by far the largest sector of the colony's agricultural economy, suffered no such problems. The dependence on the internal market which had always characterized this sector, except for a short period in the $1770 \mathrm{~s},{ }^{26}$ stood it in good stead. It is difficult to provide precise figures on the proportion of grain production which was exported, since the largest part of those exports were in the form of flour, and in the milling process the volume of the grain was reduced and its value increased. However, it is unlikely that during the second quarter of the nineteenth century more than about a tenth of the colony's grain production was ever exported, even by way of sales to provision the ships in Cape Town harbour.

In the final major section of the rural economy, that ofpastoral production, two distinct trends can be observed. On the one hand, investment in merino sheep was very strong during the $1840 \mathrm{~s}$ and $1850 \mathrm{~s}$, 
buoyed up by the demand of the British market. During this period wool overtook wine as the colony's largest export, and Port Elizabeth, with its pastoralist hinterland in the east of the colony, exceeded Cape Town as a port for the outward, though not the inward, trade of the colony. ${ }^{27}$ However, even by the mid-1850s wool accounted for no more than between 30 and 45 per cent of the value of pastoral production - and indeed well under a quarter of the total rural production - in the colony. ${ }^{28}$ The great majority of the rest consisted of meat and draft oxen, and in the nature of things these had to be consumed, or utilized, within the colony itself. ${ }^{29}$

At mid-century, then, a decade or more after the emancipation of slaves, and two decades after that of the Khoikhoi, all the main parts of the colony's agrarian economy depended primarily on the local market. However, different qualifiers are needed for each of them. The grain sector did so as always, the wine sector, increasingly, and the pastoral sector, still. They were, of course, interlinked. Growth in one part of the economy stimulated demand for other products. It is possible that the demand itself could have been sufficient to alleviate the problems that emancipation might have caused, by providing income sufficient to satisfy landowner and labourer alike. But, for this to have happened, prices would have had to have risen dramatically in the $1840 \mathrm{~s}$, whereas in fact they seem to have stayed fairly stable. Though demand was enough to sustain it, post-emancipation expansion was thus not in that sense demand-driven.

The other main possibility that has to be considered is that farmers could compensate for the loss of labour by increasing their productivity sharply. This would have entailed a considerable injection of capital. The capital was indeed available, in the form of the compensation money paid for at the emancipation of slaves. There were complaints, which have been exaggerated in later historiography, that Cape slaveowners did not receive the full value for their slaves, largely because the money had to be collected in London and the agents obviously took a commission. Nevertheless, since there was considerable competition between those vying for agency, ${ }^{30}$ and since the number of absentee slaveowners at the Cape was minimal, the majority of the $\mathcal{L} 1,193,0858 \mathrm{~s}$. $6 \mathrm{~d}$. granted by the British government to the Cape slaveowners as compensation money certainly reached the Cape. ${ }^{31}$ Some of this obviously had to be used to redeem mortgages secured on the security of slave property, but the farmers would nevertheless have had a clean slate and thus have been able to raise capital again on the credit market against the security of their landed property. This would have been available, since their pre-emancipation creditors were themselves largely residents of the colony. 
The injection of capital into the Cape colony which resulted from emancipation allowed, and in many ways gave rise to, the development of the Cape's banking system. The first private bank in the colony was established in 1837 , and within a few years several others had followed. The government-run Lombard and Discount banks were driven out of business as a result. ${ }^{32}$ The farmers found that credit was now easier to obtain, and thus cheaper. In this context, though, what needs to be asked is how a ready availability of capital could have improved the productivity of Cape farms. The most likely possibility is that guano, from Malagas Island to the north of Cape Town, gave at least some farms the added fertility they needed. The government, which shrewdly took a monopoly on the sales, made a profit of nearly $£ 150,000$ over an unspecified period in the $1840 \mathrm{~s}$, but it is difficult to specify how much manure this would have meant, nor how effective it might have been. Since guano revenues were heavily concentrated in a single year, 1845 , it cannot have been of major importance. ${ }^{33}$ It may also be that farmers could have then bought the machinery which they previously either could not afford or saw no reason to, given sufficient labour. Again they might have introduced new systems of husbandry as an attempt to compensate for labour shortage. Only a close study of the equipment present on the farms, which as yet has not been undertaken, could test the accuracy of this supposition. ${ }^{34}$ However, even in Europe both grain and wine farming remained heavily labour-intensive throughout the nineteenth century, so the potential for improvements at that date seems slight.

All in all, it would seem unlikely that either the development of new markets by itself or the import of capital could have affected the maintenance of agricultural production in wake of the emancipations. Therefore, it has to be assumed that the labour supply remained sufficient to allow the farms of the Cape Colony, both in the (largely) agricultural West and in the (largely) pastoral East, to continue at much the same level. This 'happy' result - for the farmowners at least - was in part the result of the concerted action of the landowning class, in conjunction with the colonial state, but it was also to a substantial degree serendipitous.

The landowners' offensive was able to achieve success because it was able to build on two or three decades' experience of holding the formally free Khoisan in, effectively, bondage. While the initial subjugation of the Khoisan had been accompanied by much brutality, after the first decade or so of the nineteenth century the stories of violence on the farms of the eastern, or for that matter north-western, Cape are much rarer. Rather, forms of debt peonage, the bonding of children, and thus their parents, though indentures, the refusal to allow men and women to leave a farm with their stock, and the harassment of those who were on the road 
seeking work meant that a large proportion of the Khoisan were tied to particular farms. On these they were treated as slaves, but did not have the protection which slaves enjoyed as the living repositories of the masters' capital.

These practices were the target of John Philip's Researches in South Africa. The lessons which were drawn from it were certainly thought by some whose main concern was the Caribbean to be apposite to the emancipation of slaves there. James Cropper indeed suggested the reprinting of the Researches in 1835 as a warning from South Africa to the West Indies. ${ }^{35}$ He wanted to alert the authorities there to the tricks which could be used to hold the nominally free in subjugation. But there is another side to this. In South Africa, too, the supposedly emancipatory Ordinance 50 , itself a result of the agitation of which the Researches was a part, was fairly systematically subverted at the local level. Even had they been willing to enforce it fully, which is most doubtful, the Courts simply did not have the manpower to do so. $^{36}$

With the emancipation of slaves the number of those who were free but whom the landowners considered should still be subservient increased dramatically. The result was a two-pronged offensive. The first prong was legislative. This took three forms. The first, contemporary with the abolition of slavery, was the attempt to have a vagrancy act introduced into the Colony. The Ordinance in question, which was published on 14 May 1834, empowered and required every field-commandant, fieldcornet and provisional field-cornet [the local officers of law and administration, elected from among the substantial farmers of a district] ... to apprehend all persons found within his jurisdiction, whom he may reasonably suspect of having no reasonable means of subsistence, or who cannot give a satisfactory account of themselves' ${ }^{37}$ This Ordinance was passed by the Cape's Legislative Council, largely by the votes of the 'unofficial' members, but was then submitted to the Colonial Office in London for approval before enactment.

Even before it had been tabled, Colonel T.F. Wade, who had been acting governor of the Cape and was the Ordinance's main sponsor, had, rather disingenuously, informed the Colonial Office that laws would be introduced with, as their objects

the prevention or punishment of Vagrancy... and for securing [sic] a sufficiency of labourers to the Colony by compelling not only the liberated apprentices to earn an honest livelihood, but all others who, being capable of doing so, may be inclined to lead an idle and vagabondizing life. ${ }^{38}$

In other words, the Vagrancy Act was explicitly designed to re- 
establish the control of slaveowners over their erstwhile slaves, and also of landowners in general over the Khoisan. Indeed, Ordinance 50 had already been followed by an offensive along these lines. ${ }^{39}$ For this reason, the Vagrancy Ordinance was greeted both with a large-scale movement of those Khoisan who could go to the mission stations, where they expected a degree of protection, ${ }^{40}$ and with a storm of protest, both from the missionary and other defenders of Khoisan and slave rights and from a substantial group of the Khoisan themselves. ${ }^{41}$ Essentially, they were all too well aware, on past experience, that the passing of such an Ordinance would allow the farmers to arrest any of their employees who left the farm on which they worked. This would prevent any form of bargaining as to wages or conditions by weighting the scales far too heavily in the farmers' favour. As a result, the Colonial Office disallowed the Vagrancy Bill as being incompatible with Ordinance 50 .

If the vagrancy measures failed to achieve the desired control over the labouring population, the subsequent Master and Servant Ordinance did so, to a large degree. It too had a difficult passage. The first draft which was submitted to London was rejected because its operation was limited to people of colour' ${ }^{22}$ However, shawn of such racial excrescences, a revised version became law in 1841 , and indeed remained so, in somewhat emended form, until the $1960 \mathrm{~s} .{ }^{43}$ The basic import of the measure, as John Marincowitz has noted, was that it transferred numerous aspects of the essentially civil law contract between an employer and an employee into the sphere of the criminal law. This was because the Ordinance made 'misconduct' on the part of the employee a punishable offence. Misconduct was an elastic concept, defined as including 'refusals or neglect to perform work, negligent work, damage to master's property through negligence, violence, insolence, scandalous immorality, drunkenness, gross misconduct' and so forth. ${ }^{44}$ The punishments were not so vague; offenders could be docked one month's wages, or imprisoned, with or without hard labour, for 14 days. The result was thus a more stringent labour code than that imposed on the emancipated slaves of the Caribbean or Mauritius.

Nevertheless, this was not thought to be enough. The third measure of labour control was the bill to prevent the practice of squatting on government lands, which was introduced into the Legislative Assembly on 10 October 1851 . Rightly or wrongly, many farmers considered that government land, and indeed the farms of their less scrupulous colleagues, ${ }^{45}$ was being used by potential labourers to escape the necessity of regular labour. Once again, there was considerable protest against the bill and in the event it was dropped at the final moment of its passage through the Legislature. The Western Cape landowners believed, rightly 
or wrongly, that its enactment would be the signal for an armed uprising among their labourers, and they panicked: ${ }^{46}$ One cynical official wrote of the panic that 'It has been good for the dealers in gunpowder here. ${ }^{3} 7$

The remarkable thing about the Squatters Ordinance was that it was largely unnecessary. The second prong of the landowners' offensive had seen to that. As Caribbean experience showed clearly, ex-slaves - and for that matter the emancipated Khoisan - needed independent access to land if they were to reconstitute themselves as a peasantry and thus escape their former masters' control. There were a few areas of the Eastem Cape where this was possible for a time, ${ }^{48}$ and even before emancipation a number of free blacks and their descendants had set up as market gardeners in the neighbourhood of Cape Town. In general, however, the land of the Cape had been engrossed by the landowning class to such an extent that this was impossible. This could be done, despite the low density of population, because of the highly uneven distribution of water throughout the Cape countryside. Without access to a reasonably permanent stream, an independent existence as a peasantry was not feasible, and the small communities which attempted this were both few and poverty stricken.

The main alternative for those seeking a modicum of independence was the mission stations. During the 1840 s, the number of those who were prepared to accept the discipline imposed by the missionaries increased sharply. Between around 1838 and the early 1850 s, the population of the missions of the Western Cape doubled, from around 6,000 to about $12,000.51$ In particular the southern plains of Caledon and Swellendam districts had a number of very large such stations, especially Genadendal and Elim, but there were also a number of smaller stations in Stellenbosch and Cape districts, in addition to the old established village of Mamre in the Groenkloof, in the heart of the wheat-growing Zwartland.

The mission stations could not in any way directly support the hundreds of ex-slaves who thronged to them. They could provide a house and a vegetable garden but nothing like sufficient land to provide subsistence for a family. There might be a certain amount of employment on the stations itself as teachers, or in such workshops as the famous Genadendal knife manufactory. But the great majority, at least of the men, had to find work outside, on the farms. Those who could returned to the stations every weekend, but many had to work at greater distance and would be away from home for weeks at a time. The missions could provide security from the exactions of over-exploitative farmers. Children and women - at least outside the absolute harvest peaks - spent most of their time there, but the men were absent for much of the time. ${ }^{52}$ The population figures for the stations cannot be treated as a true census, except during such 
holidays as Christmas and Easter, but rather represent those who were registered as belonging to the station.

There were other alternatives, in the villages and small towns of the Cape, and even in Cape Town which grew considerably in the years immediately after emancipation. However, places like Stellenbosch, the Paarl, Swellendam or George could not provide regular employment for the hundreds of ex-slaves who came to live there. Seasonal employment on the surrounding farms was therefore the only way to make a living. There was even a regular exodus from Cape Town for the wine and wheat harvests. The towns could provide more freedom than the mission stations, though probably inferior living conditions. ${ }^{53}$ They could not allow a significantly different way of life.

It was here that the serendipity of the Cape's labour situation after emancipation was to be found. The mission stations, and to a lesser extent the towns, of the colony were much hated by the farmers. They were seen as repositories of idleness. One farmer noted that they "have been called "reservoirs of labour" but they are more like stagnant pools, engendering pestilential vapours and requiring immediate purification'. ${ }^{54}$ However, at least in economic terms, this does not seem to have been an accurate assessment. Grain, wine and wool production all have sharp peaks in their labour requirements, for pruning, harvesting, shearing and so forth. In the Cape, these did not coincide, and indeed the timing of the wheat harvest, for instance, varied between the Cape's regions, as could be expected given the country's great distances and high relief. As a result, it is at least arguable that the most efficient use of labour under such circumstances would be the combination of a small number of tied labourers on each farm coupled to a large pool of men and women travelling round the countryside and working where they were needed at any given moment. Under slavery, this was difficult to organize, although the Khoisan might be employed as casual labourers and farmers frequently hired each other's slaves for peak periods. ${ }^{55}$ With emancipation, it could be achieved. The mission inhabitants played the role of travelling labourers, while those held in place by the contracts of the Masters and Servants Ordinance formed the fixed core of labourers on each farm. As a result it was possible for the farmers to compensate for any shortfall in labour caused by the withdrawal of many women and children from the labour force. What labour there was, was used more efficiently

It might seem, then, as though the Cape Colony formed just about the only case where the economic predictions of the abolitionists actually came true, and where freedom raised all-round productivity. Clearly, this would be overstating the matter very considerably. The restrictive legislation, such as the Masters and Servants Ordinance, and a welter of 
restrictive practices maintained, kept a high proportion of the erstwhile slaves and Khoisan in thralldom. It was not for nothing that Dr John Philip, who in the Researches in South Africa had propagated the liberal economic ideas of the Scottish enlightenment, spent the rest of his life campaigning for the dilution of Ordinance 50 and the emancipation of slaves. What the post-emancipation settlement clearly did do, though, was to divide the Cape's rural working class between those who were tied to the farms and those who had at least one foot in the relative freedom of the mission stations or the country towns, and thereby the possibility of social mobility which was denied to their fellows. There may not have been much difference between the two groups in terms of the standard of - living they enjoyed in the years immediately after emancipation. Those who remained on the farms, even if they changed employer, at least knew what to expect and were guaranteed a minimum of subsistence. Those who went to the towns risked abject poverty, and those on the mission stations had to submit to a form of discipline which was different to that they experienced under slavery, but was perhaps for some no less restricting, notably in its enforced sobriety. However, in the long term the two groups came to grow apart, in economic terms, but also in matters of culture. The inhabitants of the mission stations and at least of Cape Town had the chance to acquire education and to work their way up out of their status as agricultural labourers, or at least their descendants did. Symbolically the first school for the training of ex-slave, Khoi, and indeed African teachers was opened in Genadendal in 1838. The products of this and other such institutions became among the most typical examples of the 'Cape Coloured' elite. In contrast, those who remained as farm labourers had virtually no opportunities to escape from the cycle of - thraldom, debt peonage and alcohol addiction so characteristic of Cape rural life. ${ }^{56}$ The results of this bifurcation are still evident today.

\section{NOTES}

1. Crawford Young, Politics in the Congo: Decolonization and Independence, Princeton, 1965, p.316.

2. Susan Miers and Richard Roberts, Introduction to their The End of Slavery in Africa (Madison and London, 1989), p. 12.

3. The early settlement can best be followed in Leonard Guelke, The Southwestern Cape Colony 1657-1750: Freehold Land Grants, (Occasional Paper No 5, Geography Publication Series, Waterloo, Geography Department, University of Waterloo, Ontario, 1987). See also his 'The Early European Settlement of South Africa' (Ph.D. thesis, University of Toronto, 1974).

4. Nigel Worden, Slavery in Dutch South Africa (Cambridge, 1985), p. 27.

5. Ibid. 
6. Mary I. Rayner, 'Wine and Slaves: the Failure of an Export Economy and the Ending of Slavery in the Cape Colony, 1806-1834' (Ph.D. thesis, Duke University, 1986), Chs. 2 and 5 .

7. G. McC. Theal (ed.), Records of the Cape Colony (hereafter RCC), 36 vols, (London, 1895-1906), Vol.6, p. 75 and Vol.19, p. 387.

8. Rayner, 'Wine and Slaves', p. 58.

9. See C.C. Saunders, 'Liberated Africans in Cape Colony in the First Half of the Ninetcenth Century', International Journal of African Historical Studies, 18 (1985).

10. Andrew Bank, 'Slavery in Cape Town, 1806-1834' (MA thesis, University of Cape Town, 1991).

11. Clifton C. Crais, 'Slavery and Freedom Along a Frontier The Eastern Cape, South Africa: 1770-1838', Slavery and Abolition, 10 (1990).

12. Susan Newton-King and V.C. Malherbe, The Khoikhoi rebellion in the Eastern Cape, 7799-1803 (Cape Town, 1984); Elizabeth Elbourne, 'To Colonise the Mind Evangelicals and Missionaries in Britain and South Africa', D.Phil, Oxford, 1992.

13. On this, see D. van Arkel, G.C. Quispel and R.J. Ross, De Wijngaard des Heeren? Een onderzoek naar de wortels van 'die blanke baasskap' in Zuid Afrika (Leiden, 1983), pp. 58.9 .

14. Richard Elphick and V.C. Malherbe, "The Khoisan to 1828 , in Richard Elphick and Hermann Giliomee (eds), The Shaping of South African Society, 1652-1840, 2nd edn, (Cape Town, 1989), pp 40-2.

15. London, 1828,2 vols.

16. Whether or not these figures are strictly accurate is beside the point Probably they are not. Nevertheless, I see no reason to believe that the bias which they do contain, undoubtedly depressing the figures below their true levels, would have changed significantly during the period in question. Statements on the relative level of production in various years, which are the interesting ones, would not have been greatly affected.

17. John Marincowitz, Rural Production and Labour in the Western Cape, 1838 to 1888 , with Special Reference to the Wheat Growing Districts' (Ph.D. thesis, University of London, 1985), p. 30 .

18. There is an exception to these statements for wheat in 1832 . However, the district totals show that production in the major wheat-producing district of the Colony, the Cape district, was less than 10 per cent of that in neighbouring years $(11,000$ as opposed to 120,000 in 1831 and 142,800 in 1833), while no other crop or district shows such a pattern. The most likely reason for this is thus a clerical error, with one digit being ommitted from the tabulation before calculation of the total was made.

19. On which, see Rayner, 'Wine and Slaves', Ch. 4.

20. The increase in brandy production eliminates the possibility that Blue Book production figures in fact represent sale figures, and that post- 1838 increases were caused by decreasing on-farm consumption as the ex-slaves departed. There is no reason to believe that slaves received large quantities of brandy - as opposed to wine - before emancipation.

21. Susie Newton-King, 'The Labour Market of the Cape Colony, 1807-1828', in Shula Marks and Anthony Atmore (eds.), Economy and Society in Pre-industrial South Africa (London, 1980); Van Arkel, Quispel and Ross, De Wijngaard des Heren?; Crais, 'Slavery and Freedom along a Frontier'; Wayne Dooling, 'Slaves, Slaveowners and 'Amelioration in Graaff-Reinet, 1823-1830' (BA Honours essay, University of Cape Town, 1989); V. C. Malherbe, 'Diversification and Mobility of Khoikhoi labour in the Eastern Districts of the Cape Colony prior to the Labour Law of 1 November 1809 ' (MA thesis, University of Cape Town, 1978).

22. The figures for the colony's wool exports are to be found in Robert Ross, Adam Kok's Griquas: A Study in the Development of Stratification in South Africa (Cambridge, 1976), p. 141 .

23. Only after the cattle killing of 1856 did Xhosa labourers begin to reach the agricultural heartland of the South-West Cape. On this, see J.B. Peires, The Dead Will Arise. 
Nongqawuse and the great Xhosa Cattle-Killing Movement of 1856-7 (Johannesburg, 1989).

24. D.J. van Zyl, Kaapse Wyn en Brandewyn, 1795-1860 (Cape Town, 1974), pp. 169-70.

25. Ibid, pp 143-4, 149-50.

26. Pieter Van Duin and Robert Ross, The Economy of the Cape Colony in the Eighteenth Century (Leiden, 1987).

27. Alan Mabin, 'The Rise and Decline of Port Elizabeth, 1850-1900', International Journal of African Historical Studies, 19 (1986), pp. 275-303.

28. On this, see Robert Ross, The Relative Importance of Exports and the Internal Market for the Agriculture of the Cape Colony, 1770-1855', in G. Liesegang, H. Pasch and A. Jones (eds.), Figuring African Trade (Berlin, 1985), p. 259.

29. There was a certain trade in salt meat, to the passing ships and for export to the Mascareignes, but this was comparatively negligible.

30. In 1834 the Cape newspapers, notably the South African Commercial Advertiser and De Zuid-Afrikaan, contain numerous advertisements from those merchants who were buying up compensation clams.

31. British Parliamentary Paper 215 of 1837-8, Accounts of Slave Compensation Claims, pp. $351-3$.

32. E. H. D. Arndt, Banking and Currency Development in South Africa, 1652-1927 (Cape Town, 1928); J. Lalou Meltzer, 'The Growth of Cape Town Commerce and the role of John Fairbairn's Advertiser (1835-1859)' (MA thesis, University of Cape Town, 1989).

33. W. A. Newman, Biographical Memoir of John Montagu (London and Cape Town, 1855), p. 57. The figure which Newman gives does not tally with the much lower figures in the Cape Blue Books. I an grateful to Andrew Bank for his investigations of the latter for me.

34. Given the number of wills and inventaries, such a study is not doomed for lack of evidence.

35. Robert Ross, 'James Cropper, John Philip and the Researches in South Africa', in Hugh Macmillan and Shula Marks (eds.), Africa and Empire W. M. Macmillan, Historian and Social Critic (London, 1989).

36. L.C. Duly, 'A Revisit with the Cape's Hottentot Ordinance of 1828 ', in M. Kooy (ed,), Studies in Economics and Economic History: Essays in Honour of Professor H.M. Robertson (London, 1972).

37. Report of the Select Committee on Aborigines (British Settlements), together with the minutes of evidence, British Parliamentary Paper 538 of 1836, pp.723-4.

38. Cited in W. M. Macmillan, The Cape Colour Question: A Historical Survey (London, $1927), \mathrm{p} 234$.

39. 'Evidence of Major W.B. Dundas', BPP 538 of 1836, p. 128.

40. Macmillan, Cape Colour Question, p. 238.

41. For the former, see the evidence before the Select Committee on Aborigines, notably that provided by Capt. C. Bradford, the Rev. H.P. Hallbeck and Dr John Philip; for the latter, see Edna Bradlow, The Khol and the Proposed Vagrancy Legislation of 1834 Quarterly Bulletin of the South African Public Library, 39 (1985) and Stanley Trapido, "The Emergence of Liberalism and the Making of "Hottentot Nationalism", 1815-1834' (Unpublished paper, Institute of Commonwealth Studies, London, 1990).

42. Otherwise, so it was argued, no European workmen would ever be prepared to emigrate to South Africa.

43. Marincowitz, 'Rural Production and Labour', pp. 57-65, Colin Bundy, The Abolition of the Master and Servants Act', South African Labour Bulletin, 2 (1979).

44. Master and Servant: Documents on the Working of the Order in Council of 21 July 1846 Cape Town, 1849 , p. 3 .

45. W F. Bergh, Resident Magistrate of Malmesbury to Sec. to Gov. 20 Feb. 1849, in Legislative Council, Master and Servant: Addenda to the Documents on the working of the Order in Council of the 21st July 1846 (Cape Town, 1849), p. 191; there are also some indications that forms of share-cropping and labour tenancy were emerging in the 
aftermath of emancipation, but they were never of any great extent. See petition on the Masters and Servants Bill from the inhabitants of Wagenmakers valley, 7 Sept 1839 , Cape Archives, LCA 10/17; De Zuid-Afrikaan, 28 Sept 1848, cited in Marincowitz, Rural Production and Labour, pp. 845 .

46. For divergent views on the reality of the planned uprising, see John Marincowitz, From "Colour Question" to "Agrarian Problem" at the Cape: Reflections on the Interim", in Hugh Macmillan and Shula Marks (eds), Africa and Empire: W. M. Macmillan, Historian and Social Critic (London, 1989), pp. 155-60; Edna Bradlow, The "Great Fear" at the Cape of Good Hope, 1851-52', International Journal of African Historical Studies, 23 (1989). In general, I believe that the evidence favours Bradlow's argument that the panic was without foundation.

47. John Rainier to John Montagu, 3 Jan. 1852, in Further papers detailing an alarm in the district of Riversdale in reference to the Proposed Ordinance to prevent the practice of settling or squatting on Government Lands', Legislative Council Paper, 28 Jan. 1852, Cape Archives LCA 26/8, p.10.

48. Saul Dubow, Land, Labour and Merchant Capital. The Experience of the Graaff Reinet District in the Pre-Industrial Economy of the Cape (1852-1872), Communications of the Centre for African Studies, University of Cape Town, No, 6 (1982), pp. 63-70.

49. Bank, 'Slavery in Cape Town'.

50. Proceedings of evidence ... respecting 'squatting', esp. pp. 8-10, 19, 40-1.

51. Marincowitz, 'Rural Production and Labour', p. 41.

52. Master and Servant: Addenda contains an occupational census of the mission stations in 1848.

53. On Cape Town, see in particular Shirley Judges, 'Poverty, Living Conditions and Social Eelations: Aspects of Life in Cape Town in the 1830s' (MA thesis, University of Cape Town, 1977).

54. Master and Servant, pp.74-5, cited in Marincowitz, 'Rural Production and Labour', p. 85. This sort of reaction was a clear psychological residue of slavery. The former slaveowners could not countenance their labourers not being directly under their own control:

55. Worden, Slavery in Dutch South Africa.

56. For example, Pamela Scully, Criminality and Conflict in Rural Stellenbosch, 1870-1900' Journal of African History, 30 (1989), pp: 289-301, idem, Liquor and Labour in Stellenbosch District, 1870-1900', in Charles Ambler and Jonathan Crush (eds), Liquor and Labour in Southern Africa (Athens, Ohio, 1992), and numerous studies of twentieth-century rural Cape labour. 